\title{
Stage I Lung Cancer AJCC v6
}

National Cancer Institute

\section{Source}

National Cancer Institute. Stage I Lung Cancer A/CC v6. NCI Thesaurus. Code C8772.

Stage I includes: IA: (TI, NO, MO) and IB: (T2, N0, MO). TI: Tumor $3 \mathrm{~cm}$ or less in greatest dimension surrounded by lung or visceral pleura, without bronchoscopic evidence of invasion more proximal than the lobar bronchus. T2: Tumor with any of the following features of size or extent: More than $3 \mathrm{~cm}$ in greatest dimension. Involves main bronchus, $2 \mathrm{~cm}$ or more distal to the carina. Invades the visceral pleura. N0: No regional lymph metastasis. M0: No distant metastasis. (AJCC 6th ed.) - 2003 